\title{
Inhibition of Digestive Enzymes, Antioxidant and Free Radical Scavenging Capacities of Stem Bark Extracts of Coula edulis Baill (Olacaceae)
}

\author{
Eric Beyegue $^{1}$, Boris G. K. Azantsa ${ }^{1}$, Angie M-A Mbong ${ }^{1} \&$ Julius E. Oben $^{1}$ \\ ${ }^{1}$ Department of Biochemistry, Faculty of Science, University of Yaoundé 1, Cameroon \\ Correspondence: Boris Gabin Kingue Azantsa, Department of Biochemistry, Faculty of Science, University of \\ Yaounde 1, Yaounde, Cameroon. Tel: 237-677-920-184. E-mail: borisazantsa@yahoo.fr
}

Received: July 14, 2020

Accepted: September 4, $2020 \quad$ Online Published: September 10, 2021

doi:10.5539/jfr.v10n5p1

URL: https://doi.org/10.5539/jfr.v10n5p1

\begin{abstract}
Prolonged hyperglycemia enhances oxidative stress. Bioactive compounds extracted possess antioxidant, anti-free radical potentials or the ability to reduce blood sugar levels. The objective of this study was to evaluate the antioxidant properties of extracts of stem bark of Coula edulis Baill., their abilities to trap free radicals and glucose, as well as their ability to inhibit $\alpha$-amylase and invertase activities. In vitro assays were used to test the trapping capacity of extracts on DPPH, ABTS, NO, and $\mathrm{OH}$ radicals; to evaluate the antioxidant capacity, the activity of glycosylation and the capacity of inhibition of the activities of $\alpha$-amylase and invertase were conducted. Also, phenolic, flavonoid and alkaloid contents of extracts were determined. Results showed that extracts of the stem bark of $C$. edulis have anti-radical properties. The extracts chelate DPPH, hydroxyl (OH), nitrite oxide (NO), ABTS radicals, and even glucose. The $\mathrm{IC}_{50}$ values varied depending on the nature of the extraction solvent. Ethanolic extract has the highest polyphenolic content $(289.12 \pm 30.31 \mu \mathrm{g}$ catechin equivalent/g), flavonoids $(1.12 \pm 0.09 \mu \mathrm{g}$ quercetin equivalent/g) and alkaloids $(5.54 \pm 0.59 \mu \mathrm{g}$ quinin equivalent/g). The extracts also reduce invertase and $\alpha$-amylase activities. $C$. edulis extracts present strong antioxidant potentials and can be used as a source of natural antioxidants for the prevention of oxidative stress and hyperglycemia.
\end{abstract}

Keywords: Coula edulis Baill., antioxidant, amylase, invertase

\section{Introduction}

Oxidation process is one of the most important means for producing free radicals in food, drugs and even living systems (Khettaf et al., 2016). Free radicals and hyperglycaemia which can be induce by a lower digestive enzymes activities play a major role in many of today's diseases (Kim et al., 2015; Budin et al., 2018). Further, more evidences have accumulated and indicated key roles for reactive oxygen species (ROS) and other oxidants such as singlet oxygen species, superoxide, hydroxyl, peroxyl, nitroxide and ferrous in causing numerous disorders (Saeed et al., 2012). When, free radicals are present in higher concentration beyond the antioxidant capacity of a biological system, this gives a disturbance between the pro-oxidant/antioxidant balance in favour of the former, rise to an imbalance known as oxidative stress (Zima et al., 2001). ROS are normally generated during normal metabolism and energy production in the body (Mavi et al., 2004). This production helps the normal healthy tissues to perform physiological roles such as signaling molecules, regulation of signal transduction and gene expression, activation of receptor and nuclear transduction among others (Valko et al., 2006). Oxidative stress status forced by free radicals may cause lipid peroxidation, protein damages, inflammation, autoimmune pathologies, DNA damage and altering cell signalling pathways and modulating gene expression. Overwhelming literature evidence has implicated the role of free radicals in the progression of heart diseases, neurodegenerative diseases, cancer, aging process (Oluyemi et al., 2007) and complications in diabetes among others (Raghuveer and Tandon, 2009). However, cells have a comprehensive array of antioxidant defense mechanisms to reduce free radical formation or limit their damaging effects (Badmus et al., 2011). These antioxidants mechanism protect human cells against free radical damage by enzymes such as superoxide dismutase (SOD) and catalase, or non-enzymatic compounds such as ascorbic acid, tocopherol and glutathione (Moukette et al., 2016). Then, these antioxidants are used to counteract the harmful effects of free radicals. Given that, they stabilize or deactivate free radicals, often before they attack targets in biological cells (Nunes $e t$ 
al., 2012), antioxidants can prevent or delay the oxidation of the substrate. Sometimes these protective mechanisms are disrupted by various pathological processes, and antioxidant supplements are vital to combat oxidative damage. A lower digestive enzymes activity favours the high plasma glucose level, along with metabolic diseases. Accumulating evidence indicates that obesity and many chronic diseases are associated with systemic oxidative stress, whereas consuming polyphenols attenuates these disease conditions (Zhang et al., 2015).

Several studies have demonstrated a distinct correlation between the higher intake of plant foods and lower risk of mortality from diseases (Chidambaram et al., 2013). Phenols are repeatedly implicated as natural antioxidants in fruits, vegetables and other plants (Yeh et al., 2011). Plant derived products may contain phenols and others phytochemicals that could act as antioxidant compound. These bioactive natural products have been proved to have unique pharmacological properties (Kannan et al., 2013) throughout their ability to prevent the destructive processes caused by oxidative stress (Athiperumalsami et al., 2010). Also, these compounds have the ability to bind to enzymes and inhibit their activity. The presence of inhibitors of carbohydrate and glycerides hydrolysing enzymes such as invertase and $\alpha$-amylase, in plant derived products helps in the control of blood glucose level in patients with type 2 diabetes and to prevent obesity (Zhang et al., 2015). Hence, the growing interest to find cheap, renewable and abundant sources of antioxidants has fostered research on current consumption plants. Coula edulis B., (commonly known as African walnut), grows naturally in evergreen forests from Sierra Leone to Democratic Republic of Congo (Moupela et al., 2011).

Previous studies on $C$. edulis $B$. revealed the presence of phenolic compounds which have been shown as having antiplasmodial activity (Zofou et al., 2011). Further, in the folk medicine, the bark is used in treatments of gastro-intestinal infections, anaemia, diarrhoea, anti-inflammation and anti-microbial health's care (Bukola et al., 2008). Indeed, different part of $C$. edulis B. has been several using in African traditional pharmacopeia, some of these beneficial effects could be related to the antioxidant potent (Dembitsky, 2006). In fact, the exploration, characterization and application of natural antioxidants are the focus of several research teams in the Sub-Saharan Africa (Biapa et al., 2011; Nyangono et al., 2012; Kuate et al., 2014). The main objective of this study was to investigate the in vitro antioxidant, free radical scavenging properties, and some digestive enzymes effects of hexane dichloromethane, ethanol and aqueous extract from stem barks of $C$. edulis B. against in vitro oxidative stress.

\section{Materials and Methods}

\subsection{Instruments}

The samples were weighed using an OHAUS model PA64 microbalance. An ika Rv 10 Control type rotary evaporator was used to collect the different fractions of extracts. A Vanguard brand V6500 Iohazard micro-centrifuge was used to separate the constituents of mixtures. The absorbance of solutions was measured using a Genesys 20 brand spectrophotometer.

\subsection{Chemicals \& Reagents}

The different reagents used in this study (Hexane, Dichloromethane, Ethanol (95\%), Methanol, Sodium Carbonate, Folin-Ciocalteu, Chloride acid, 1,10-phenanthroline, Naphtylenediamine chloride, 2,2-diphenyl-1-picrylhydrazyl, Gallic Acid, Aluminum Chloride, Potassium Acetate, Quercetin, Cathechin, Quinin, Ascorbic Acid, Hydrochloric Acid, Iron Chloride, Sodium dihydrogen phosphate, Sulfuric Acid, Dibasic hydrogen phosphate, Potassium ferricyanide, Ammonium molybdate, Sodium Nitroprusside, Sulfanilicacid, Acetic acid and N-(1-naphthyl)-Ethylenediamine dihydrochloride) were purchased from Merck (Germany).

\subsection{Plant Collection}

The stem barks of Coula edulis B. Stem bark were collected in July 2014 in Mbalmayo, a locality in the Centre Region of Cameroon. The plant was identified and authenticated at the Cameroon National Herbarium in Yaounde and a voucher specimen has been deposited under the number 46305 HNC.

\subsection{Extraction}

For each extract, 500 grams of the powder were macerated at room temperature in $3 \mathrm{~L}$ of boiling water or ethanol/water (1:4) mixture, for 48 hours.

Stem bark of plant $(2400 \mathrm{~g})$ were collected and shade, dried at $50^{\circ} \mathrm{C}$ indoor drying room for $48 \mathrm{~h}$. The dry sample powder obtained in last step (2000 g) was mixed successively with hexane, dichloromethane, ethanol $(95 \%)$ and distilled water at room temperature (1/4: w/v) reagents. After homogenization, mixture was macerated for $48 \mathrm{~h}$ at room temperature and filtered through Whatman \#2 filter paper (Whatman International Limited, Kent, England). The filtrate was concentrated using a rotary evaporator (ika Rv 10 Control) under 
reduced pressure at $40^{\circ} \mathrm{C}$ to yield four samples of $C$. edulis B. extract: hexane (CE hexane $31 \mathrm{~g}$ ), dichloromethane (CE DCM, $70 \mathrm{~g}$ ), ethanol (CE EtOH, $96 \mathrm{~g}$ ) and aqueous (CE Aq $53 \mathrm{~g}$ ) extract of stem back.

Each sample were dissolved in $95 \%$ ethanol to make a concentration of $1 \mathrm{mg} / \mathrm{ml}$ and then diluted to prepare the series concentrations for antioxidant assays. Reference chemicals were used for comparison in all assays.

\subsubsection{DPPH Radical Scavenging Activity Test}

The free radical scavenging activity of the fractions was measured in vitro by 2,2- diphenyl-1-picrylhydrazyl (DPPH) assay according to the method described and modified by (Brand-Williams et al., 1999; Sánchez Moreno et al., 1998). The stock solution was prepared by dissolving $24 \mathrm{mg}$ DPPH with $100 \mathrm{ml}$ methanol and stored at $20^{\circ} \mathrm{C}$ until required.

One (1) $\mathrm{ml}$ aliquot of this solution was mixed with $20 \mu \mathrm{l}$ of the sample at various concentrations $(10-160$ $\mu \mathrm{g} / \mathrm{ml})$. The reaction mixture was shaken well and incubated in the dark for $30 \mathrm{~min}$ at room temperature. Then the absorbance was taken at $517 \mathrm{~nm}$. The control was prepared as above without any sample. The same procedure was used for the ascorbic acid $(1 \mathrm{mg} / \mathrm{ml})$ used as standard. The scavenging activity was estimated based on the percentage of DPPH radical scavenged as the following equation:

$$
\text { Scavenging effect }(\%)=[(\text { Abs Control }- \text { Abs Sample }) / \text { Abs Control }] \times 100
$$

\subsubsection{ABTS Radical Scavenging Activity Test}

The 2, 2'-azinobis (3-ethylbenzthiazoline-6-sulphonic acid), commonly called ABTS cation scavenging activity was performed according to (Re et al., 1999) with some modifications. Briefly, ABTS solution (7 mM) was reacted with potassium persulfate $(2.45 \mathrm{mM})$ solution and kept for overnight in the dark to yield a dark coloured solution containing ABTS radical cations.

The mixture was stored in the dark at room temperature for $12 \mathrm{~h}$ before used. The ABTS ${ }^{+}$solution was diluted (1: $10 \mathrm{v} / \mathrm{v})$ with a solution of phosphate buffer $(0.1 \mathrm{M}, \mathrm{pH} 7.4, \mathrm{NaCl} 150 \mathrm{mM})$ to an absorbance of $2.27 \pm 0.05$ at $734 \mathrm{~nm}$. After addition of $20 \mu \mathrm{l}$ of extract sample or ascorbic acid used as standard to $1 \mathrm{ml}$ of diluted ABTS solution, absorbance was measured at $734 \mathrm{~nm}$ after incubation at room temperature for 30 minutes. The control was prepared as above without any sample. The decrease in absorption was used for calculating scavenging effect values. The following equation was used to determine the percentage of the radical scavenging activity of each extract.

$$
\text { Scavenging effect }(\%)=[(\text { Abs Control }- \text { Abs Sample }) / \text { Abs Control }] \times 100
$$

\subsubsection{Hydroxyl Radical Scavenging Activity Test}

The hydroxyl radical scavenging activity was determined as earlier described by Halliwell et al., (1987). The reaction mixture consisted of $\mathrm{FeCl}_{3}(300 \mu \mathrm{M})$, EDTA $(780 \mu \mathrm{M})$, 2-deoxyribose $(2.8 \mathrm{mM})$, ascorbic acid (300 $\mu \mathrm{M}), \mathrm{H}_{2} \mathrm{O}_{2}(4 \mathrm{mM})$ and aliquots of extracts in a final volume of $1 \mathrm{ml}$. All reagents were dissolved in potassium phosphate buffer $\left(20 \mathrm{mM}, \mathrm{pH}\right.$ 7.4). This was then incubated at $37^{\circ} \mathrm{C}$ for $1 \mathrm{~h}$. After incubation, $1 \mathrm{ml}$ of TCA $(2.8 \%)$ and TBA $(1 \%)$ were added to the reaction mixture and incubated at $100^{\circ} \mathrm{C}$ for $20 \mathrm{~min}$. A control tube was prepared similarly effect except that the extract was replaced with methanol. The absorbance was read spectrophotometrically at $532 \mathrm{~nm}$. All measurements were done in triplicate and the \% inhibition was calculated using following formula.

$$
\text { Scavenging effect }(\%)=[(\text { Abs Control }- \text { Abs Sample }) / \text { Abs Control }] \times 100
$$

\subsubsection{Nitric Oxide Radical Scavenging Activity Test}

Nitric oxide scavenging activity was determined according to the Griess Illosvoy reaction (Green et al., 1982). The lesser of the production of nitrite ion was measured according to (Sreejayan and Rao, 1997). Various concentrations of the extracts $(0.5 \mathrm{ml})$ were added in a final volume of $3 \mathrm{ml}$. After incubation for $60 \mathrm{~min}$ at $37^{\circ} \mathrm{C}$, Griess reagent [N-(1-Naphthyl) ethylenediamine $(0.1 \%)$ and sulphanilic acid (1\%) in $\mathrm{H}_{3} \mathrm{PO}_{4}(5 \%)$ ] was added. The pink chromophore generated during diazotization of nitrite ions with sulphanilamide and subsequent coupling with $\mathrm{N}-(1-\mathrm{Naphthyl)}$ ethylenediamine was measured spectrophotometrically at $540 \mathrm{~nm}$. Ascorbic acid was used as a positive control. The control was prepared as above without any sample. The scavenging effect (\%) of the nitric oxide was calculated using the formula:

$$
\text { Scavenging effect }(\%)=[(\text { Abs Control }- \text { Abs Sample }) / \text { Abs Control }] \times 100
$$

\subsubsection{Phosphomolybdate Assay (Total Antioxidant Capacity)}

The total antioxidant activity of the extracts was evaluated by green phosphomolybdenum complex according to a method described (Prieto et al., 1999). An aliquot of $10 \mu \mathrm{l}$ of the extract solution was mixed with $1 \mathrm{ml}$ of 
reagent solution ( $0.6 \mathrm{M}$ sulphuric acid, $28 \mathrm{mM}$ sodium phosphate and $4 \mathrm{mM}$ ammonium molybdate) in a micro centrifuge tube.

The tubes were incubated in a dry thermal bath at $95^{\circ} \mathrm{C}$ for $60 \mathrm{~min}$. After cooling, the absorbance of the mixture was measured at $695 \mathrm{~nm}$ against a blank. A typical blank contained $1 \mathrm{ml}$ of the reagent solution and the appropriate volume of the solvent and incubated under the same conditions. Ascorbic acid was used as standard. The antioxidant capacity was estimated using following formula:

$$
\text { Antioxidant effect }(\%)=[(\text { Abs Control }- \text { Abs Sample }) / \text { Abs Control }] \times 100
$$

\subsection{Evaluation of Glucose Scavenging Activity}

The glucose scavenging activity was determined according to the method of Bertrand described by Kebieche (2009). At first we have introduced glucose $(100 \mathrm{mg} / \mathrm{l} ; 1 \mathrm{ml})$, sample of extract $(100 \mu \mathrm{l})$ at various concentrations $(50-1600 \mu \mathrm{g} / \mathrm{ml})$, followed by addition of picric acid $(0.4 \mathrm{M} ; 1 \mathrm{ml})$. The control was prepared as above without any sample. The mixture was incubated 30 minutes at room temperature. The absorbance of the solution was read at $570 \mathrm{~nm}$.

$$
\text { Glucose scavenging }(\%)=[(\text { Abs Control }- \text { Abs Sample }) / \text { Abs Control }] x 100
$$

\subsection{Evaluation of the Power of the Extracts to Inhibit the Activity of $\alpha$-amylase}

The $\alpha$-amylase inhibitory activity was determined according to the method of Bernfield (1951). Adding $250 \mu 1$ of appropriate dilutions of the vegetable extracts prepared in different concentrations $(0.0375$ to $1.2 \mathrm{mg} / \mathrm{ml})$ and 500 $\mu \mathrm{l}$ of $0.02 \mathrm{M}$ sodium phosphate buffer $(\mathrm{pH} 6.9$ with $0.9 \% \mathrm{NaCl}$ ) containing rodent pancreatic $\alpha$-amylase (EC 3.2.1.1) $(0.5 \mathrm{mg} / \mathrm{ml})$ were pre-incubated at $25^{\circ} \mathrm{C}$ for 10 minutes. Then, $250 \mu \mathrm{l}$ of $1 \%$ starch solution in $0.02 \mathrm{M}$ sodium phosphate buffer $(\mathrm{pH} 6.9$ with $0.9 \% \mathrm{NaCl})$ was added to the reacting mixture.

Thereafter, the reaction mixture was incubated at $37^{\circ} \mathrm{C}$ for $10 \mathrm{~min}$ and stopped with $500 \mu \mathrm{l}$ of dinitrosalicylic acid (DNSA). The mixture was then incubated in a boiling water bath for $5 \mathrm{~min}$, and cooled to room temperature. The reaction mixture was then diluted by adding of distilled water until $10 \mathrm{ml}$. The absorbance measured at 540 nm.

Then, the $\alpha$-amylase inhibitory activity was calculated as percentage inhibition.

$$
\text { Inhibition }(\%)=[(\text { Abs Control }- \text { Abs Sample }) / \text { Abs Control }] \times 100
$$

\subsection{Evaluation of the Power of the Extracts to Inhibit the Activity of Invertase}

The invertase inhibitory activity was determined according to the method of Melius, (1971). Invertase catalysed hydrolysis of sucrose. The first step was consisted to isolate of invertase from Baker's Yeast followed by the purification of sample.

At first introduce $50 \mu \mathrm{L}$ of extracts in different concentrations $(5,10,20$ and $40 \mathrm{mg} / \mathrm{mL})$ into $1.0 \mathrm{ml}$ of substrate solution (composed of $20 \mathrm{mM}$ sucrose in $40 \mathrm{mM}$ sodium acetate buffer at $\mathrm{pH} 4.80$ ). Those mixtures were pre-incubated at an ambient temperature of $20-24^{\circ} \mathrm{C}$ ) during 5.0 minutes. At 30 second intervals for each concentration (30 and $60 \mathrm{~s})$, small aliquots $(0.05 \mathrm{ml})$ of each enzyme-containing fraction are quantitatively transferred and gently mixed into disposable test-tubes where the invertase reaction is allowed to proceed for a precise time of 5.0 minutes.

At the end of each 5.0 minutes' reaction period at a temperature of $37^{\circ} \mathrm{C}$, the invertase activity in each tube is instantaneously stopped at 30 second intervals by denaturation with the rapid addition of $2.0 \mathrm{ml}$ of alkaline DNS solution (composed of $0.20 \mathrm{M} \mathrm{NaOH}, 23 \mathrm{mM} \mathrm{3,5-dinitrosalicylate,} \mathrm{and} 0.53 \mathrm{M}$ sodium potassium tartrate). After each reaction is "stopped", the entire set of assay tubes is transferred to a boiling water bath for 10 minutes. Under these conditions, the D-Fructose produced in step 1 rapidly isomerizes to D-glucose which, along with the other mole of glucose produced by the enzyme reaction, reduces the brightly yellow-coloured 3, 5-dinitrosalicylate to dark orange-coloured solutions of 3-amino-5-nitrosalicylate. The entire set of assay tubes is then cooled in a beaker of tap water before each solution is diluted to a final volume of $6.1 \mathrm{ml}$ with the addition of $3.0 \mathrm{ml}$ of $50 \mathrm{mM}$ sodium acetate buffer at $\mathrm{pH} 4.8$.

The control tube was prepared exactly as one of the assay tubes in steps 1 and 2 except for the volume of extract added to the substrate solution in step 1 is replaced with water. The absorbance of the solution in each disposable test tube at $540 \mathrm{~nm}$.

$$
\text { Inhibition }(\%)=[(\text { Abs Control }- \text { Abs Sample }) / \text { Abs Control }] \times 100
$$




\subsection{Determination of Phenolic and Alkaloid Contents}

\subsubsection{Evaluation of the Total Phenolic Content}

Determination of total phenolic content was determined using Folin-Ciocalteu (FC) reagent according to the method of Singleton and Rossi (1965), with a slight modification. Briefly, the plant extract (30 $\mu \mathrm{l})$ was mixed with $1 \mathrm{ml}$ of FC reagent (previously diluted 10-fold with distilled water) and incubated for $5 \mathrm{~min}$ at ambient temperature, then $(0.7 \mathrm{ml} ; 7 \%) \mathrm{Na}_{2} \mathrm{CO}_{3}$ solution was added. After incubation at ambient temperature for $30 \mathrm{~min}$ into dark room, the absorbance was measured at $750 \mathrm{~nm}$. The phenolic content was evaluated from a catechin standard curve.

\subsubsection{Evaluation of the Total Flavonoid Content}

The total flavonoid content was determined with aluminium chloride $\left(\mathrm{AlCl}_{3}\right)$ according to a known method of Bahorun et al., (1996). We were using quercetin as a standard.

The plant extract $1 \mathrm{ml}\left(1 \mathrm{mg} / \mathrm{ml}\right.$; ethanol $\left.95^{\circ}\right)$, was added to $\mathrm{AlCl}_{3}\left(1 \mathrm{ml}, 10 \%\right.$, ethanol $\left.95^{\circ}\right)$, followed by potassium acetate $(1 \mathrm{ml}, 1 \mathrm{M})$. After a further $30 \mathrm{~min}$, the reaction mixture was allowed to stand at room temperature for $10 \mathrm{~min}$. The absorbance was measured at $420 \mathrm{~nm}$. All tests were performed three times. The flavonoid content was calculated from a quercetin standard curve.

\subsubsection{Assessment of the Alkaloid Content}

Total alkaloids contents were determined by the method of Singh et al., (2003), which involves the oxidation of alkaloids by iron (III). To each $1 \mathrm{ml}$ of sample $(1 \mathrm{mg} / \mathrm{ml})$ add of $\mathrm{FeCl}_{3}(1 \mathrm{ml}, 0.25 \mathrm{M})$ in $\mathrm{HCl}(0.5 \mathrm{M})$ and 1 , 10-phenanthroline $(1 \mathrm{ml}, 0.05 \mathrm{M})$ in ethanol. The flasks were placed in water bath maintained at $70^{\circ} \mathrm{C}$ for 30 minutes. The absorbance of red-colored complex was measured at $510 \mathrm{~nm}$ against a reagent blank. All tests were performed three times. The alkaloids content was calculated from a quinin standard curve. All of these tests were carried out in triplicates.

\subsection{Phytochemical Screening of CEE Bark}

Phytochemical screening stem bark of $C$. edulis extracts for the presence of alkaloids, cardiac glycosides, flavonoids, saponin, phlobatannins, tannins and terpenoids was carried out.

\subsubsection{Detection Test for Alkaloids}

One (1) $\mathrm{ml}$ of stem bark of $C$. edulis extracts was boiled with $1 \mathrm{ml}$ of $1 \% \mathrm{HCl}$ for 5 minutes. The mixture was warmed and filtered (Harborne, 1973). The filtrate was treated separately with few drops of potassium mercuric iodide (Mayer's reagent) Saeed et al., (2012). Turbidity or precipitation with either of these reagents was taken as evidence for existence of alkaloids.

\subsubsection{Saponin Detection Test}

In the presence of water, saponins form emulsions after stirring (Trease et al., 1989). $0.5 \mathrm{~g}$ of CEE extracts were added to $5 \mathrm{~mL}$ of distilled water. The mixture was shaken for a few minutes. The appearance and persistence of the emulsion after $20 \mathrm{~min}$ was used as evidence of the presence of saponins.

\subsubsection{Terpenoids Test}

The presence of terpenoids in the CEE extracts was carried out by mixing $2 \mathrm{~mL}$ of extract $(1 \mathrm{mg} / \mathrm{mL})$ of CEE with $2 \mathrm{~mL}$ of chloroform, then $3 \mathrm{~mL}$ of concentrated $\mathrm{H}_{2} \mathrm{SO}_{4}$ added. Under these conditions, the appearance of a reddish brown coloration at the interface attested to the presence of terpenoids (Harborne, 1973).

\subsubsection{Cardiac Glycoside Detection Test}

Two (2) $\mathrm{ml}(10 \mathrm{mg} / \mathrm{ml}$ in ethanol) of $C$. edulis extracts were mixed with $2 \mathrm{ml}$ of glacial acetic acid having one drop of $\mathrm{FeCl}_{3}$ solution. To the mixture obtained $1 \mathrm{ml}$ of concentrated $\mathrm{H}_{2} \mathrm{SO}_{4}$ was added to form a layer. The presence of brown ring of the interface indicated deoxy sugar characteristic of cardiac glycosides (Trease et al., 1989).

\subsubsection{Phlobatannin Detection Test}

One hundred (100) mg of CEE extracts were boiled in $1 \%$ aqueous hydrochloric acid; the deposition of a red precipitate indicated the presence of phlobatannins (Trease et al., 1989).

\subsubsection{Flavonoids Test}

Five hundred (500) $\mathrm{mg}$ of CEE extracts were suspended in $5 \mathrm{ml}$ of distilled water to get the filtrate. $2 \mathrm{ml}$ of dilute $\mathrm{NaOH}$ solution was added to $2 \mathrm{ml}$ of filtrate followed by few drops of concentrated hydrochloric acid. Presence 
of flavonoids was confirmed by yellow colouration (Sofowara, 1993).

\subsection{Statistical Analyses}

The results were presented as mean \pm SEM of triplicate assays. Analyses of data was conducted using one-way analysis of variance (ANOVA) followed by Tukeys test and Dunnett's multiple test (SPSS program version 18.0 for Windows, IBM Corporation. The $\log$ probit was used to determinate the $\mathrm{IC}_{50}$ were used to achieve the Pearson Correlation Analysis (PCA). The differences were considered as significant at $p<0.05$.

\section{Results and Discussions}

\subsection{Extraction Yield}

Depending on the nature of solvent used, extraction and fractions yield was recorded differently. With 4.8 and $3.5 \% \mathrm{CE}$ EtOH and $\mathrm{CE}$ Aq appear respectively to be the best solvents for fractionation giving the maximum yield

3.2 Preliminary phytochemical screening

C. edulis soluble extracts demonstrated the presence of alkaloids, cardiac glycosides, flavonoids, saponins, phlobatannins, tannins and phlobatannins. Only cardiac glycosides and phlobatannins were not present in all the extracts.

Table 1. Phytochemical constituents of $C$. edulis extracts

\begin{tabular}{llllll}
\hline Compound Class & \multicolumn{2}{l}{ Samples } & & \\
\cline { 2 - 6 } & CE hexane & CE dichloromethane & CE ethanolic & CE aqueous \\
\hline Saponins & + & + & + & + \\
Flavonoids & + & + & + & + \\
Tannins & + & + & + & + \\
Phlobatannins & - & + & + & + \\
Alkaloids & + & + & + & + \\
Cardiac glycosides & - & - & + & + \\
\hline
\end{tabular}

$+=$ presence of a constituent

- = absence of a constituent

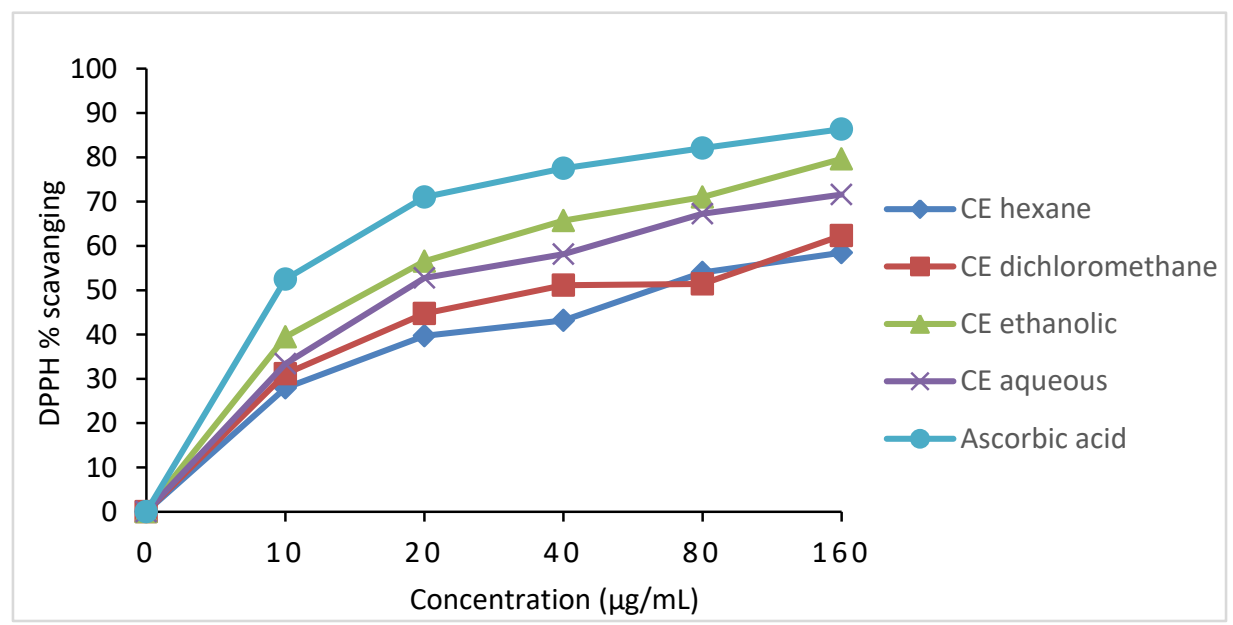

Figure 1. DPPH anti radical activity of hexane, dichloromethane, ethanolic and aqueous extracts of C. edulis stem bark extract

Each value represents a mean $\pm \mathrm{SD}(\mathrm{n}=3)$ 


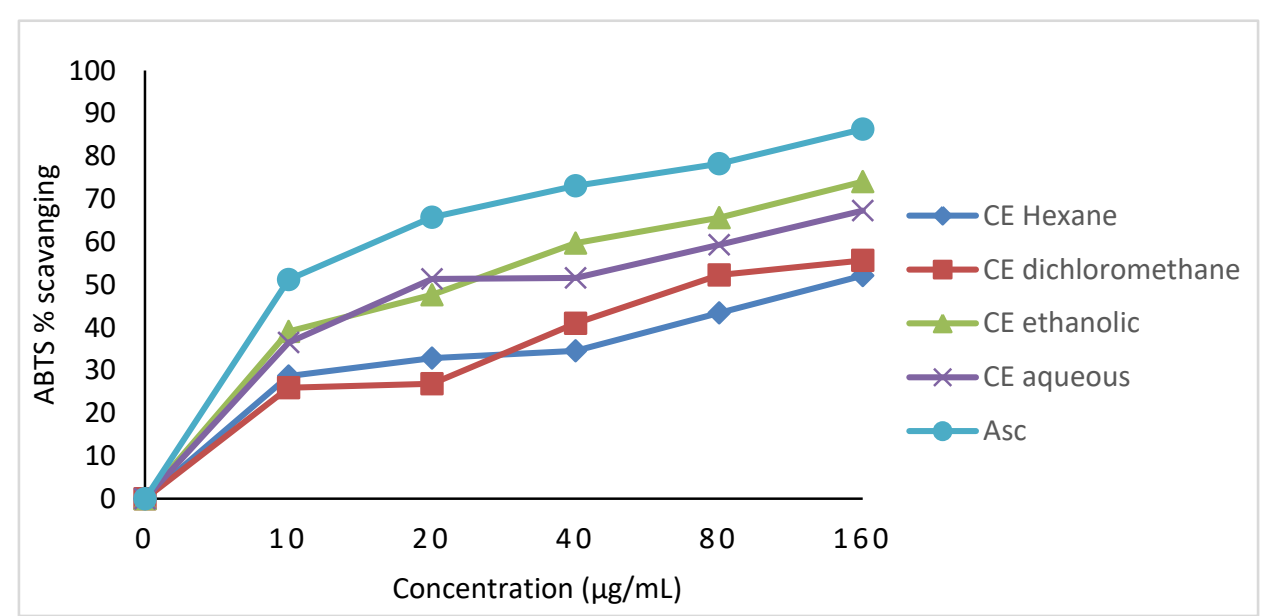

Figure 2. ABTS anti radical activity of hexane, dichloromethane, ethanolic and aqueous extracts of C. edulis stem bark extract

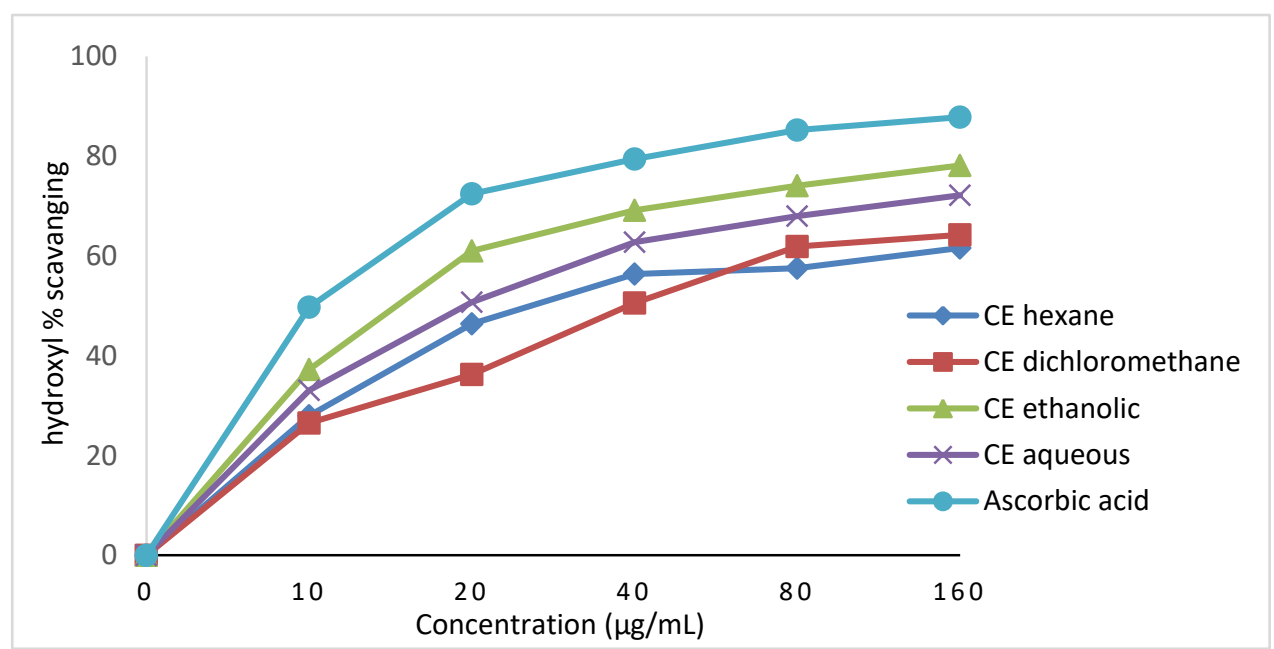

Figure 3. Hydroxyl anti radical activity of hexane, dichloromethane, ethanolic and aqueous extracts of C. edulis stem bark extract

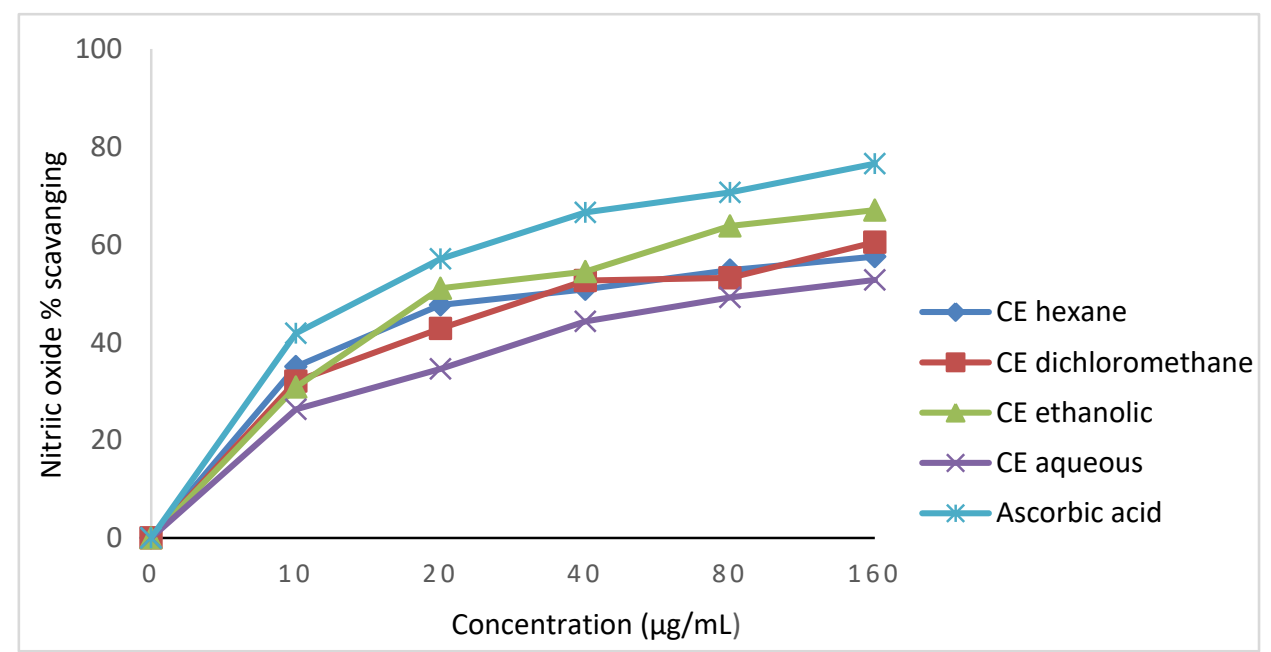

Figure 4. Nitric oxide anti radical activity of hexane, dichloromethane, ethanolic and aqueous extracts of $C$. edulis stem bark extract 


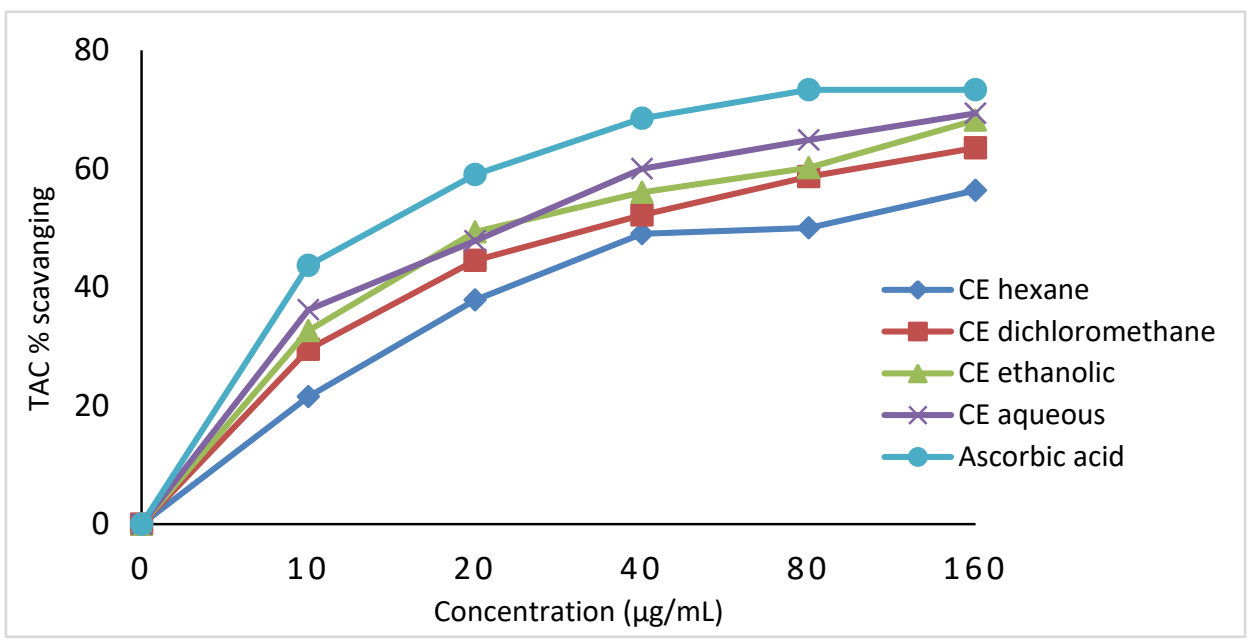

Figure 5. Total antioxidant capacity hexane, dichloromethane, ethanolic and aqueous extracts of C. edulis stem bark extract

Each value represents a mean $\pm \operatorname{SD}(n=3)$

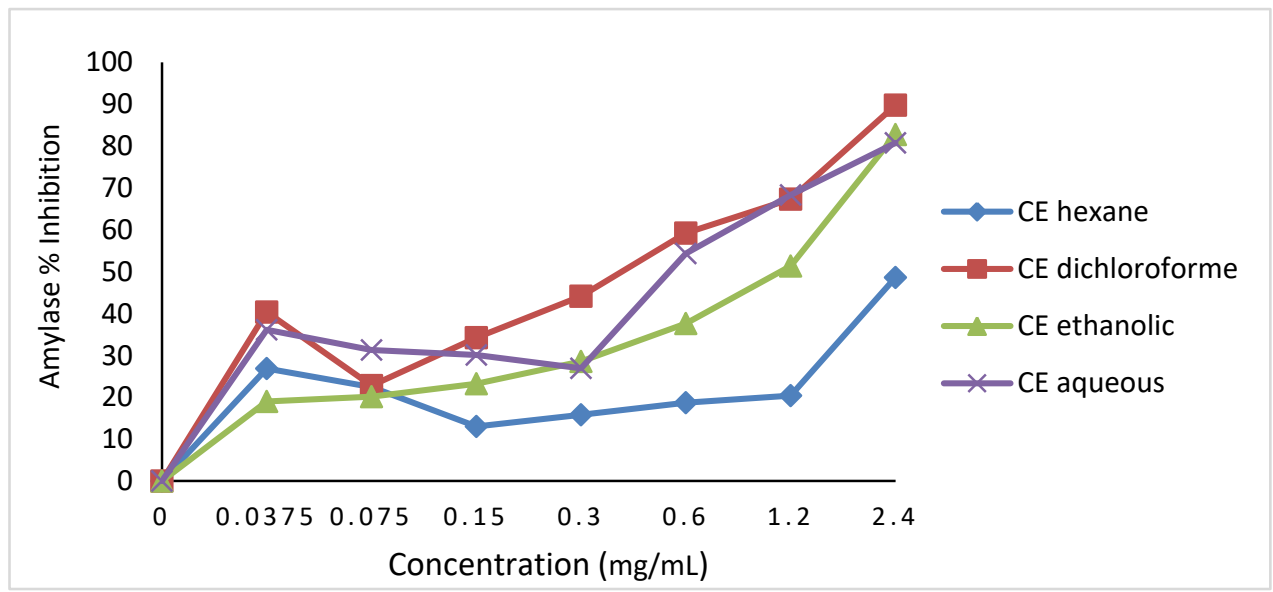

Figure 6. Alpha amylase inhibitory activity hexane, dichloromethane, ethanolic and aqueous extracts of $C$. edulis stem bark extract

Values represent mean \pm standard deviation, $\mathrm{n}=3$

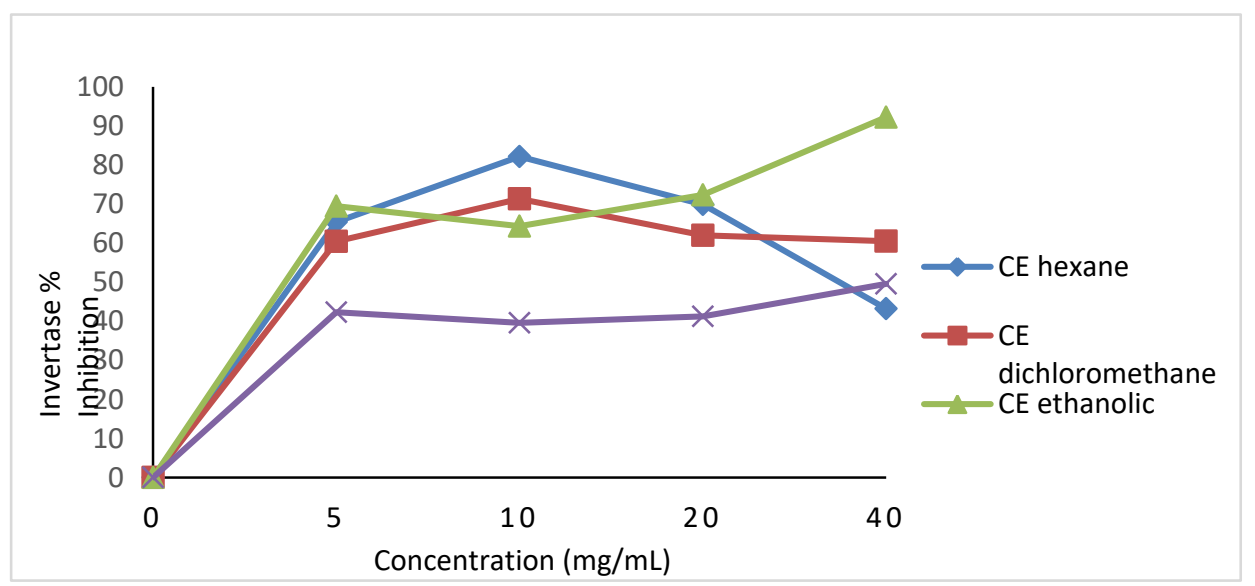

Figure 7. Invertase inhibitory activity of hexane, dichloromethane, ethanolic and aqueous extracts of $C$. edulis stem bark extract

Values represent mean \pm standard deviation, $\mathrm{n}=3$ 


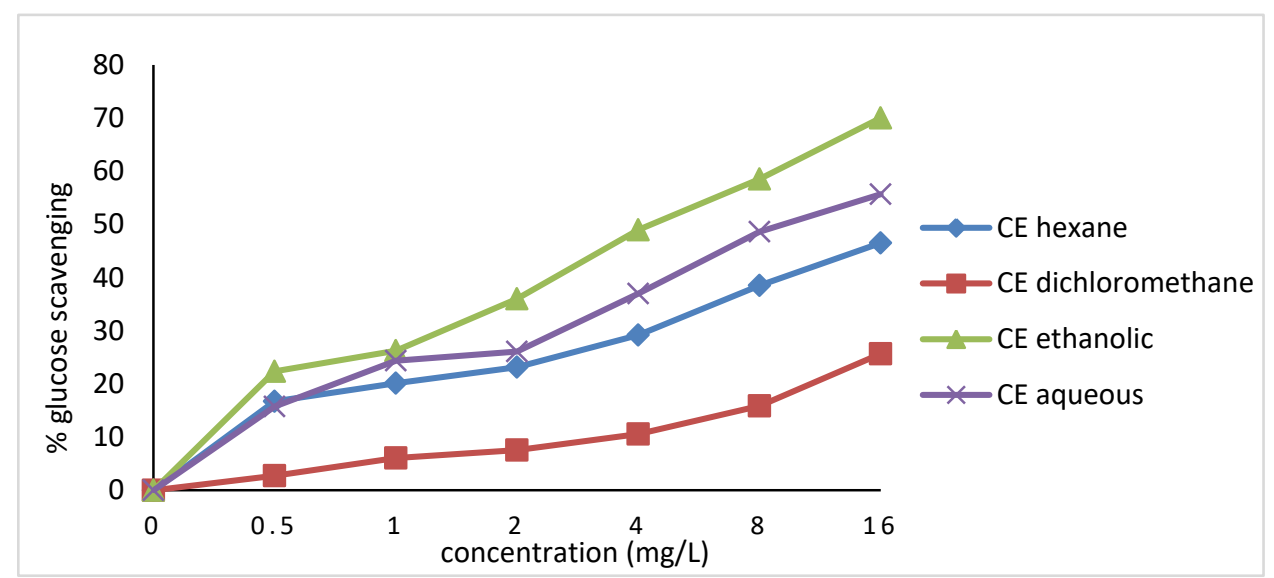

Figure 8. Glucose scavenging activity of hexane, dichloromethane, ethanolic and aqueous extracts of $C$. edulis stem bark extract

Values represent mean \pm standard deviation, $\mathrm{n}=3$

Table 2. Different values of $\mathrm{IC}_{50}$ of $C$. edulis extracts on the different radicals tested

\begin{tabular}{|c|c|c|c|c|c|c|}
\hline & IC $_{50}$ value & $\mathrm{mL}$ ) of $\mathbf{r}$ & al scaven & & & \\
\hline $\begin{array}{l}\text { Plant extracts/ } \\
\text { Chemical }\end{array}$ & $\begin{array}{l}\text { DPPH } \\
\text { radical }\end{array}$ & $\begin{array}{l}\text { ABTS } \\
\text { radical }\end{array}$ & $\begin{array}{l}\text { Hydroxyl } \\
\text { radical }\end{array}$ & $\begin{array}{l}\text { Nitric oxide } \\
\text { radical }\end{array}$ & TAC Assay & $\begin{array}{l}\text { Glucose } \\
\text { scavenging }\end{array}$ \\
\hline CE hexane & $106.50 \pm 7.66$ & $\mathrm{e}_{\mathrm{e}}^{210.30 \pm 6.11}$ & $72.78 \pm 1.32$ & $79.21 \pm 1.36^{\mathrm{c}}$ & ${ }_{d}^{115.00 \pm 13.18}$ & $5737.0 \pm 263.4^{\mathrm{C}}$ \\
\hline $\begin{array}{l}\mathrm{CE} \\
\text { dichloromethan } \\
\text { e }\end{array}$ & $91.43 \pm 5.33^{\mathrm{b}}$ & & $44.98=$ & $85.78 \pm 3.28^{\mathrm{c}}$ & $77.57 \pm 4.96^{\mathrm{c}}$ & $\underset{d}{88992.0 \pm 370.4}$ \\
\hline CE ethanolic & $46.30 \pm 3.35^{\mathrm{a}}$ & $56.62 \pm 0.19^{\mathrm{b}}$ & $\begin{array}{l}43.13 \pm 2.29 \\
b\end{array}$ & $63.33 \pm 1.75^{\mathrm{D}}$ & $60.75 \pm 2.42^{\mathrm{D}}$ & $887.9 \pm 21.23^{\mathrm{a}}$ \\
\hline CE aqueous & $56.14 \pm 1.29^{\mathrm{a}}$ & ${ }_{c}^{68.19 \pm 1.06}{ }^{b}$ & $54.5 \pm 2.98^{\mathrm{c}}$ & $134.10 \pm 17.39$ & $58.09 \pm 0.58^{\mathrm{b}}$ & $1864.0 \pm 102.1^{\mathrm{b}}$ \\
\hline Ascorbic acid & $39.86 \pm 4.55^{\mathrm{a}}$ & $34.75 \pm 0.51^{\mathrm{a}}$ & $31.06 \pm 0.83$ & $44.98 \pm 1.38^{\mathrm{a}}$ & $41.95 \pm 0.83^{\mathrm{a}}$ & ND \\
\hline
\end{tabular}

Each value in the table is represented as mean $\pm \mathrm{SD}(\mathrm{n}=3)$. Values with different superscripts down the column are statistically different $\mathrm{p}<0.05$.

Table 3. Total phenolic, flavonoid and alkaloids contents $C$. edulis extracts

\begin{tabular}{llll}
\hline & $\begin{array}{l}\text { Total phenolic } \\
(\boldsymbol{\mu g} \text { catechin equivalent/g) }\end{array}$ & $\begin{array}{l}\text { Total flavonoid } \\
(\boldsymbol{\mu g} \text { quercetin equivalent/g) }\end{array}$ & $\begin{array}{l}\text { Alkaloids } \\
(\boldsymbol{\mu g} \text { quinin equivalent/g) }\end{array}$ \\
\hline CE hexane & $2.20 \pm 0.17^{\mathrm{a}}$ & $0.38 \pm 0.02^{\mathrm{a}}$ & $1.97 \pm 0.30^{\mathrm{a}}$ \\
$\mathbf{C E}$ dichloromethane & $3.95 \pm 0.90^{\mathrm{a}}$ & $0.45 \pm 0.02^{\mathrm{a}}$ & $1.74 \pm 0.12^{\mathrm{a}}$ \\
$\mathbf{C E}$ ethanolic & $289.11 \pm 30.31^{\mathrm{c}}$ & $1.12 \pm 0.09^{\mathrm{b}}$ & $5.54 \pm 0.59^{\mathrm{b}}$ \\
$\mathbf{C E}$ aqueous & $87.70 \pm 0.86^{\mathrm{b}}$ & $0.51 \pm 0.03^{\mathrm{a}}$ & $3.14 \pm 1.37^{\mathrm{a}}$ \\
\hline
\end{tabular}

Each value in the table is represented as mean \pm SD $(n=3)$. Values with different superscripts down the column are statistically different $\mathrm{p}<0.05$. 
Table 4. Different values of $\mathrm{IC}_{50}$ of alpha - amylase and invertase activity of $C$. edulis extracts

\begin{tabular}{lll}
\hline $\mathrm{IC}_{\mathbf{5 0}}$ values $(\mathbf{m g} / \mathbf{m L})$ & of enzyme inhibition \\
\hline Plant extracts & alpha - amylase & invertase \\
\hline CE hexane & $634.00 \pm 21.42^{\mathrm{c}}$ & $41.18 \pm 0.49^{\mathrm{c}}$ \\
CE dichloromethane & $0.71 \pm 0.01^{\mathrm{a}}$ & $14.72 \pm 0.39^{\mathrm{b}}$ \\
CE ethanolic & $3.17 \pm 0.03^{\mathrm{b}}$ & $13.39 \pm 0.43^{\mathrm{ab}}$ \\
$\mathbf{C E}$ aqueous & $1.06 \pm 0.02^{\mathrm{a}}$ & $13.03 \pm 0.24^{\mathrm{a}}$ \\
\hline
\end{tabular}

Each value in the table is represented as mean \pm SD $(n=3)$. Values with different superscripts down the column are statistically different $\mathrm{p}<0.05$.

Table 5. Results of the Pearson correlation of the different in vitro antioxidant assays

\begin{tabular}{lllllllll}
\hline Tests & ABTS & DPPH & OH & NO & TAC & Polyphenols & Flavonoids & Alkaloids \\
\hline ABTS & 1 & & & & & & & \\
DPPH & $0.943^{*}$ & 1 & & & & & & \\
OH & 0.593 & 0.413 & 1 & & & & & \\
NO & 0.063 & 0.033 & 0.014 & 1 & & & & \\
TAC & $0.958^{*}$ & $0.817^{*}$ & 0.673 & 0.115 & 1 & & & \\
Polyphenols & 0.571 & 0.728 & 0.305 & 0.111 & 0.386 & 1 & & \\
Flavonoids & 0.477 & 0.599 & 0.367 & 0.229 & 0.319 & $0.966^{*}$ & 1 & \\
Alkaloids & 0.568 & 0.745 & 0.249 & 0.082 & 0.376 & $0.993^{*}$ & $0.934^{*}$ & 1 \\
\hline
\end{tabular}

*: significant values $p=0.05$ (bilateral test). ABTS: ABTS radical scavenging test; DPPH: DPPH radical scavenging test; $\mathrm{OH}: \mathrm{OH}$ radical scavenging test; NO: NO radical scavenging test; Total antioxidant activity: Phosphomolybdenum test; Polyphenol: Polyphenol assay; Flavonoids: Flavonoid assay; Alkaloids: Alkaloid assay.

Table 6. Correlations between the $\mathrm{IC}_{50}$ values of antioxidant activities and phenolic, flavonoids and alkaloids content of C. edulis

\begin{tabular}{llll}
\hline \multirow{2}{*}{ Assays } & \multicolumn{3}{l}{ Correlation R } \\
\cline { 2 - 4 } & Polyphenols & Flavonoids & Alkaloids \\
\hline IC $_{\mathbf{5 0}}$ of glucose scavenging ability & 0.239 & 0.131 & 0.308 \\
$\mathbf{I C}_{\mathbf{5 0}}$ of alpha amylase inhibition & 0.211 & 0.204 & 0.183 \\
$\mathbf{I C}_{\mathbf{5 0}}$ of invertase inhibition & 0.238 & 0.223 & 0.212 \\
\hline
\end{tabular}

Each value in the table is represented as mean $\pm \operatorname{SD}(n=3)$.

\subsection{Scavenging Potential of Different Radicals}

\subsubsection{Anti-radical Activity on DPPH}

The scavenging effects of samples on DPPH radical (Figure 1). All the extracts demonstrated scavenging activities which varied depending on the solvent used. The scavenging effects were in the following order: $\mathrm{CE}$ $\mathrm{EtOH}>\mathrm{CE} \mathrm{Aq}>\mathrm{CE} \mathrm{DCM}>\mathrm{CE}$ hexane. Then, the extract $\mathrm{CE}$ EtOH and CE Aq showed a higher inhibitory potential while they exhibited the lowest $\mathrm{IC}_{50}$ values of scavenging DPPH radicals for the $\mathrm{CE} \mathrm{EtOH}$ and $\mathrm{CE} \mathrm{Aq}$ were $46.30 \pm 3.35$ and $56.14 \pm 1.29 \mu \mathrm{g} / \mathrm{ml}$, respectively (Table 2). Though the antioxidant potential of extracts was found to be low $(p<0.05)$ than those of ascorbic acid with the $\mathrm{IC}_{50}$ in order of 46.30 to $106.50 \mu \mathrm{g} / \mathrm{ml}$.

\subsubsection{Anti-radical Activity for ABTS}

Extracts of $C$. edulis have all shown a significant ability to trap the ABTS radical. However, this anti-radical power varied depending on the nature of the solvent and the concentration of extract $(10-160 \mu \mathrm{g} / \mathrm{mL}$ ) (Figure 1b). According to these results presented in Figure 2, the extracts can be classified according to their capacity to capture the ABTS radicals in the following order: CE Ethanol> CE Aqueous> CE DICHLOROMETHANE > CE hexane. These results also showed that the $\mathrm{IC}_{50}$ of all the extracts varied from 56.62 to $210.30 \mu \mathrm{g} / \mathrm{mL}$ depending on the type of solvent used. However, these values remain significantly higher than that of ascorbic acid, the $\mathrm{IC}_{50}$ value of which was $34.75 \pm 0.51 \mu \mathrm{g} / \mathrm{mL}$ 


\subsubsection{Anti-radical Activity for Hydroxyl Radical}

Hydroxyl radical scavenging activity was quantified by measuring the inhibition of the degradation of 2-deoxyribose by the free radicals generated by the Fenton reaction. The hydroxyl radical scavenging activity of C. edulis extract and its derived fractions can be ranked as $\mathrm{CE} \mathrm{EtOH}>\mathrm{CE}$ DCM $>\mathrm{CE} \mathrm{Aq}>\mathrm{CE}$ hexane (Table 2). All the extracts showed antioxidant activity in dose dependent manner at concentration $10-160 \mu \mathrm{g} / \mathrm{ml}$ (Figure 3). In the present investigation, the $\mathrm{IC}_{50}$ value of hydroxyl radical scavenging activity for the $\mathrm{CE} \mathrm{EtOH}$ and $\mathrm{CE}$ dichloromethane was $43.13 \pm 2.29$ and $44.98 \pm 1.38 \mu \mathrm{g} / \mathrm{ml}$ while for ascorbic acid was $31.06 \pm 0.83$ $\mu \mathrm{g} / \mathrm{ml}$ (Table 3). The markedly strong $(\mathrm{p}<0.05)$ antioxidant response of $\mathrm{CE}$ EtOH in comparison with ascorbic acid.

\subsection{Anti-radical Activity of Nitric Oxide}

The results nitric oxide scavenging potential of the different extract samples represented in the Figure 4 showed that the inhibitory potential of the different samples increased with the concentration. CE EtOH extract showed the lower potential from the lower to the higher concentration. $\mathrm{CE} \mathrm{EtOH}$ and $\mathrm{CE}$ hexane extracts exhibited the highest inhibitory potential (Figure 4) with the respectives $\mathrm{IC}_{50}$ value equal to $63.33 \pm 1.75$ and $79.21 \pm 1.36$ $\mu \mathrm{g} / \mathrm{ml}$. Nevertheless, the values of extracts are significant higher to ascorbic acid that $\mathrm{IC}_{50}$ value was $44.98 \pm 1.38$ $\mu \mathrm{g} / \mathrm{ml}$.

\subsection{Antioxidant Activity of Extracts by the TAC Method}

The phosphomolybdate method or the total antioxidant capacity (TAC) of the different plant extracts are shown in the Figure 5. We noted that CE Aq extract had the higher antioxidant capacity using TAC method compared to the other extracts. The antioxidant capacity of various solvent fractions of $C$. edulis was found to decrease in this order: $\mathrm{CE} \mathrm{Aq}>\mathrm{CE}$ EtOH $>\mathrm{CE} \mathrm{DCM}>\mathrm{CE}$ hexane extracts. However, the phosphomolybdate antioxidant capacity, the $\mathrm{IC}_{50}$ of $\mathrm{CE} \mathrm{Aq}(58.09 \pm 0.58 \mu \mathrm{g} / \mathrm{ml})$ was higher compared to that of ascorbic acid $(41.95 \pm 0.83$ $\mu \mathrm{g} / \mathrm{ml})$.

\subsection{Protective Property of Extract Samples Against a-amylase and Invertase Activities}

Figure 6 and Figure 7 showed the results of the effect of the extracts on digestives enzymatic activities. From Figure 6, we can observe that $\mathrm{CE}$ dichloromethane presented the $\alpha$-amylase $\%$ inhibition higher than the other extracts with an $\mathrm{IC}_{50}$ of $0.71 \pm 0.01 \mu \mathrm{g} / \mathrm{mL}$, followed by CE aqueous with an $\mathrm{IC}_{50}$ of $1.06 \pm 0.02 \mu \mathrm{g} / \mathrm{mL}$. Figure 7 showed $\mathrm{CE}$ aqueous had the better invertase \% inhibition effects. C. edulis effect on this enzyme decreased in this order: $\mathrm{CE}$ aqueous $>\mathrm{CE}$ ethanolic $>\mathrm{CE}$ dichloromethane $>\mathrm{CE}$ hexane. $\mathrm{CE}$ aqueous have $\mathrm{IC}_{50}$ of $13.03 \pm$ $0.24 \mu \mathrm{g} / \mathrm{mL}$.

\subsection{Protective Property of Extract Samples on Scavenging of Glucose}

Figure 8 showed that CEE have an in vitro glucophage activity. All the extracts showed glucophage activity in dose dependent manner at concentration $50-1600 \mu \mathrm{g} / \mathrm{ml}$. In the present study, the effect of thes extracts are ranged in this order: $\mathrm{CE} \mathrm{EtOH}>\mathrm{CE} \mathrm{Aq}>\mathrm{CE}$ hexane $>\mathrm{CE}$ DCM. However, $\mathrm{CE}$ EtOH and CE Aq had presented the best effect on glucose scavenging activity with the $\mathrm{IC}_{50}$ of $891.75 \pm 31.06 \mu \mathrm{g} / \mathrm{ml}$.

\subsection{Polyphenols, Flavonoids and Alkaloids Contents}

Table 3 summarizes the levels of polyphenols, flavonoids and alkaloids compounds in CEE ranging from the solvent. The obtained results showed that all the CEE content polyphenols with a level dependent of solvent. The results had expressed as micrograms of catechin equivalents by $\mathrm{g}$ dried extract for total polyphenol and as micrograms of quercetin equivalents by $\mathrm{g}$ dried extract for flavonoids.

Also, the CE EtOH $(289.10+30.32)$ [ $\mu \mathrm{g}$ catechin equivalent/g dried extract] and CE Aq $(87.70+0.85[\mu \mathrm{g}$ catechine equivalent/g dried extract] have the highest polyphenol contents compared to other extracts. The highest concentration of flavonoid $(1.12+0.09 \mu \mathrm{g}$ quercetin equivalent/g dried ext.) was identified in the $\mathrm{CE}$ $\mathrm{EtOH}$ meanwhile the $\mathrm{CE} \mathrm{Aq}$ had the second highest concentration of flavonoid with $(0.51+0.03 \mu \mathrm{g}$ quercetin equivalent/g dried extract). Further, $\mathrm{CE}$ EtOH presented the best levels of alkaloids with $(1.12+0.09) \mu \mathrm{g}$ quinine equivalent/g dried ext.).

The positive correlation between TAC, flavonoids contents and ABTS, OH, NO was noted (Table: 4). Further, a better correlation was observed between alkaloids and glucose scavenging, on the other hand between polyphenols and alpha amylase, invertase inhibition (Table 6).

\section{Discussion}

Free radicals are known to play a definite role in a wide variety of pathological manifestations. Antioxidants 
fight against free radicals and protect us from various diseases. They prevent or delay the oxidation of the substrate (Proestos et al., 2013). They exert their action either by scavenging the reactive oxygen species or protecting the antioxidant defence mechanisms (Umamaheswari and Chatterjee, 2008). Further, many synthetic drugs protect against oxidative damage but they have adverse side effects. An alternative solution to the problem is to consume natural antioxidants from food supplements and traditional medicines (Yazdanparast and Ardestani, 2007). Several studies demonstrated that plant derived antioxidants may be useful in preventing the deleterious consequences of oxidative stress (Matsinkou et al., 2012; Nyangono et al., 2013). This is a reason of natural antioxidant stimulates the research interest on the investigation of protective effects of natural antioxidants. This study demonstrated the free radical scavenging and antioxidant effects of $C$. edulis a Cameroonian non-timber forest product which the walnuts are used like foods and stem bark are used in local traditional plates. The phytochemical screenings of $C$. edulis different parts of plant have also been determined by Bukola et al., (2008).

Stable DPPH radicals are widely used to evaluate the antioxidant activities of proton-donating substances according to hydrogen donating ability. DPPH - radicals accept electrons or hydrogen radicals to form stable diamagnetic molecules. The effect of extracts on DPPH radical results for their hydrogen donating ability (Al-Temimi and Choudhary, 2013). This is associated with the decrease in absorbance of DPPH· radical along with a discoloration from purple to yellow.

The results showed an overall DPPH scavenging activity of all the tested extracts. Among them, CE EtOH and CE Aq extracts showed a higher DPPH scavenging potential. These results prove that $C$. edulis stem bark extracts act as proton donors. High scavenging ability in ethanolic extract may attribute to high level of antioxidant components in the extract, which react rapidly with DPPH radicals and reduce most DPPH radical molecules (Yeh et al., 2013). Several studies stated that the polyphenols from plants extracts are responsible in a large part for the DPPH scavenging potential (Omoregie and Osagie, 2012)

ABTS assay measures the relative ability of antioxidant to scavenge the $\mathrm{ABTS}^{\circ+}$ generated in aqueous and organic solvent systems. In the presence of hydrogen-donating antioxidants, pre-formed radical cation reduced it to ABTS in a concentration-dependent manner. Our results showed that all the tested samples demonstrated a scavenging potential of the ABTS with varying inhibitory potential with the CE EtOh extract demonstrating the relative highest ABTS inhibitory power. This result confirmed that the presence of higher flavonoids level (Biskup et al., 2013), could be explained by the structure, number and arrangement of their phenolic hydroxyl group responsible for these activities (Matsinkou et al., 2012).

Biologically, the hydroxyl radical is widely believed to be generated when hydrogen peroxide reacts with $\mathrm{Fe}(\mathrm{II})$ (Fenton reaction). The hydroxyl radical has been described as a highly damaging species which can cause lipid peroxidation and enormous biological damage (Aurand et al., 1977). When the sample is mixed with $\mathrm{Fe}(\mathrm{II})$, it may alter the activity of $\mathrm{Fe}(\mathrm{II})$ by chelation. Our $\mathrm{IC}_{50}$ values indicate that the scavenging potential of the extracts increased proportional to the concentration, which is depicted by the low intensity of red colour. The extract CE $\mathrm{EtOH}$ exhibited a highest HO- scavenging power among all the extracts. Antioxidants in food (such as ascorbic acid) may act as pro-oxidants by reducing Fe (III) to Fe(II) and make the HO- generation catalytic. (Huang et al., 2005).

It is well known that nitric oxide radical has an important role in various inflammatory processes. It is associated with several diseases (Tylor et al., 1997). Oxygen reacts with nitric oxide to generate nitrite and peroxynitrite anions which act as free radicals. Under physiological conditions, peroxynitrite forms a compound with carbon dioxide dissolved in body fluid. This compound is believed to be responsible for the oxidative damage of proteins (Squadrito and Pryor, 2002). Our results showed that extracts can tightly inhibits nitrite formation by directly competing with oxygen in the reaction with nitric oxide. CE dichloromethane and CE Aq showed the lowest NO radical scavenging power whereas $\mathrm{CE}$ EtOH and $\mathrm{CE}$ hexane exhibited the highest NO- inhibitory potential. Previous research reported that the antioxidant activity of phenols against NO- radical is related to the quantity, number and position of hydroxyl groups in the molecule (Sahreen et al., 2011).

Given that, the nature of the inhibition is ambiguous because there are several potential inhibition pathways, studies recommended several testing methods for the investigation of antioxidant activity of extracts from natural resources (Gordon, 1990, Huang et al., 2005). The antioxidant capacity of the fractions was measured spectrophotometrically through phosphomolybdenum method, based on the reduction of Mo (VI) to Mo (V) by the test sample and the subsequent formation of green phosphate/Mo (V) compounds. The present study demonstrated that $\mathrm{CE}$ EtOH and $\mathrm{CE}$ Aq exhibited the highest antioxidant capacity for phosphomolybdate 
reduction. Recent studies have shown that many flavonoid and related polyphenols contribute significantly to the phosphomolybdate scavenging activity of medicinal plants (Sharififar et al., 2009, Khan et al., 2012).

Polyphenols have antioxidant properties correlated to their chemical structure, the number and arrangement of their phenolic hydroxyl groups (Bravo, 1998; Pandey and Rizvi, 2009). That said, polyphenols are known to be the effective antioxidants in plants due to their hydroxyl groups. Scientists also said that the purpose of used solvents have different polarity to extract phenolic compounds from plants with a high degree of accuracy (Razali et al., 2012). They were mentioned that the high polar solvents have a high effectiveness of antioxidants such as ethanol. The ethanol extract exhibited the highest total phenolic content, whereas the contents obtained with hexane extract were much smaller that is in agreement with other reports (Ao et al., 2008).

Typical phenols with antioxidant activity have been characterized as phenolic acids and flavonoids. Flavonoids are one categories of phenolic compounds which are naturally occurring in plants and are thought to have positive effects on human health. Flavonoids have been shown to be highly effective scavengers of most oxidizing molecules, including singlet oxygen, and various free radicals (Bravo, 1998) implicated in several diseases. So comparable with the findings in the literature for other extracts of plant products (Sahreen $e t$ al., 2011) our results suggested that phenolic acids and flavonoids may be the major contributors for the antioxidant activity as the $\mathrm{IC}_{50}$ values of radical scavenging activity of various soluble fractions of $C$. edulis and the contents of polyphenols or flavonoids exhibited significant correlation.

Some alkaloids (ajmaline, ajmalicine and reserpine) has been developed in tablets of pharmaceutical formulations (Singh et al., 2004). According to literature review ethanol was the better extracted solvent. Alkaloids are a group of bioactive compounds. It has been recognized that alkaloids show antioxidant property and their effects on human nutrition and health care are considerable (Kumpulainen and Salonen, 1999). Mechanism of action of alkaloids is through inhibition of peroxidation (Kessler et al., 2003).

$\alpha$-amylase (EC 3.2.1.1.) is an enzyme which catalyses the breakdown of starch into sugars in the mouth and small intestine. The inhibitory effects of dietary polyphenols against $\alpha$-amylase have being proved by several researchers (Xiao et al., 2013). CE dichloromethane and CE Aq had shown a significant $(p<0.05)$ better inhibition of $\alpha$-amylase activity as a result of a low decrease of starch concentration in middle (Figure 6). Otherwise, Figure 7 showed that $\mathrm{CE} \mathrm{Aq}$ and $\mathrm{CE}$ EtOH had the better inhibition effect on invertase activity. In fact, invertase (E.C. 3.2.1.26 - $\beta$-D-fructofuranosidase) is another digestive enzyme. It catalyses the sucrose hydrolysis producing an equimolar mixture of glucose and fructose named inverted sugar. This result is in agreement with a recent worked reported by Oboh et al., (2010) where red and white ginger inhibited invertase activity in vitro. Polyphenols may affect glycaemia through different mechanisms, including the inhibition of glucose absorption in the gut or of its uptake by peripheral tissues (Pandey and Rizvi, 2009). Plant phytochemicals are mild inhibitors of $\alpha$-amylase and strong inhibitors of invertase activity (Kwon et al., 2007). A property that confers advantage over synthetic drugs such as acarbose; use by diabetics in the management of postprandial blood glucose, which strongly inhibit $\alpha$-amylase.

Glycosylation is the reaction in which a carbohydrate, such as a glycosyl donor, is attached to a hydroxyl or other functional group of another molecule. Our results further show that CEE were potent glycophagic compounds. Nevertheless, CE EtOH had presented the better glycophagic effect probably due to the level of polyphenols. Many compounds such as proteins, polyphenols that have a glycosylation activity (Xiao and Kai, 2011). Thereafter, theses researchers said, glycosylation of flavonoids decreases the affinities for plasma proteins by 1-3 orders of magnitude depending on the conjugation site and the class of sugar moiety, along with oxidative stress.

\section{Conclusion}

On the basis of the results obtained in the present study, it is concluded that, ethanolic extract of $C$. edulis stem bark, which contains large amounts of phenolic, flavonoids and alkaloids compounds, exhibits high antioxidant and free radical scavenging activities. CEE also chelate glucose and inhibited $\alpha$-amylase and invertase (key enzyme linked to type-2 diabetes) activities. These in vitro assays indicate that this plant extract is a significant source of natural antioxidant, which might be helpful in preventing the progress of various oxidative stresses.

\section{Author Contributions}

EB and BGKA designed the study; EB performed the laboratory analysis; EB and MMA performed the statistical analysis; EB and BGKA performed the data interpretation. BGKA drafted the manuscript; JEO supervised the study. All authors read and approved the final version of the Manuscript. 


\section{Funding}

This research was funded by the Laboratory of Nutrition and Nutritional Biochemistry (LNNB), University of Yaounde 1, Cameroon

\section{Acknowledgments}

This work was supported by the Laboratory of Nutrition and Nutritional Biochemistry, and many students of the University of Yaounde 1.

\section{Conflicts of Interest}

The authors declare there is no conflict of interest.

\section{References}

Al-Temimi, A., \& Choudhary, R. (2013). Determination of Antioxidant Activity in Different Kinds of Plants in vivo and in vitro by Using Diverse Technical Methods. Journal of Nutrition Food Sciences, 3(184), 1-6. https://doi.org/10.4172/2155-9600.1000184

Ao, C., Li, A., Elzaawely, A. A., Xuan, D. T., \& Twata, S. (2008). Evaluation of antioxidant and antibacterial activities of Ficus microcarpa L. fill extract. Food Control, 19, 940-948. https://doi.org/10.1016/j.foodcont.2007.09.007

Athiperumalsami, T., Devi, Rajeswari, V., Hastha-Poorna, S., Kumar, V., \& Louis-Jesudass, V. (2010). Antioxidant activity of seagrasses and seaweeds. Botanica Marina, 53(3), 251-257. https://doi.org/10.1515/BOT.2010.032

Aurand, L. W., Boone, N. H., \& Giddings, G. G. (1977). Superoxide and singlet oxygen in milk lipid peroxidation. Journal of Dairy Sciences, 60, 363-369. https://doi.org/10.3168/jds.S0022-0302(77)83874-5

Azantsa, B. G. K., Takuissu, G. R., Tcheumeni, E. J., Fonkoua, M., Dibacto, K. R. E. Ngondi, J. L., \& Oben, J. E. (2019). Antihyperglycemic mechanisms of Allium sativum, Citrus sinensis and Persea americana Extracts: Effects on inhibition of digestive enzymes, glucose adsorption and absorption on yeast cells and psoas muscles. Diabetes Research Open Journal, 6(1), 1-9. https://doi.org/10.17140/DROJ-6-143

Badmus, J., Adedosu, T., Fatoki, J., Adegbite, V., Adaramoye, O., \& Odunola, O. (2011). Lipid peroxidation inhibition and antiradical activities of some leaf fractions of Mangifera indica. Acta Poloniae Pharmaceutica - Drug Research, 68, 23-29. https://doi.org/10.1001/archsurg.1997.01430350027005

Bernfield, P. (1951). Enzymes of starch degradation and synthesis. Advances in enzymology and related subjects of biochemistry, 12, 379-380. https://doi.org/10.1002/9780470122570.ch7

Biapa, N., Oben, J., \& Ngogang, J. (2011). Scavenging radical kinetic and Antianaemic Screening Properties of some Medicinal Plants used in Cameroon. International Journal of Applied Research in Natural Products, 4 , 29-35. https://doi.org/10.1016/j.jfca.2010.07.007

Biskup, I., Golonka, I., Gamian, A., \& Sroka, Z. (2013). Antioxidant activity of selected phenols estimated by ABTS and FRAP methods. Postepy Higieny Medycyny Doswiadczalnej (Online), 67, 958-963. https://doi.org/10.5604/17322693.1066062

Bravo, L. (1998). Polyphenols: chemistry, dietary sources, metabolism and nutritional significance. Nutrition Reviews, 56, 317-333. https://doi.org/10.1111/j.1753-4887.1998.tb01670.x

Budin, S. B., Rahman, W. Z. A., Jubaidi, F. F., Yusof, N. L. M., Taib, I. S., \& Zainalabidin, S. (2018). Roselle (Hibiscus sabdiriffa) Polyphenol-Rich Extract Prevents Testicular Damage of Diabetic Rats. Journal of Applied Pharmaceutical Science, 8(02), 065-070. https://doi.org/10.7324/JAPS.2018.8210

Bukola, C., Adebayo, T., \& Kola, K. A. (2008). Antimicrobial activities of Coula edulis. Research journal of medicinal plant, 2(2), 86-91. https://doi.org/10.3923/rjmp.2008.86.91

Chidambaram, U., Pachamuthu, V., Natarajan, S., Elango, B., Narayanan, S., \& Ramkumar, K. M. (2013). In vitro evaluation of free radical scavenging activity of Codariocalyxmotorius root extract. Asian Pacific Journal of Tropical Medicine, 6, 188-194. https://doi.org/10.1016/S1995-7645(13)60021-8

Dembitsky, V. M. (2010). anticancer activity of natural and synthetic acetylenic lipids. Lipids, 41(10), 883-924. https://doi.org/10.1007/s11745-006-5044-3

Gordon, M. H. (1990). The mechanism of antioxidant action in vitro. In B. J. F. Hudson (Ed.), Food Antioxidants (pp. 1-18). Elsevier Applied Food Science Series. Springer, Dordrecht. 
https://doi.org/10.1007/978-94-009-0753-9_1

Green, L. C., Wagner, D. A., Glogowski, J., Skipper, P. L., Wishnok, J. S., \& Tannenbaum, S. R., (1982). Analysis of nitrate, nitrite and 15N nitrate in biological fluids. Analytical Biochemistry, 126, 131-138. https://doi.org/10.1016/0003-2697(82)90118-X

Gulcin, I., Oktay, M., Kufrevioglu, I., \& Aslam, A. (2002). Determination of antioxidant activity of lichen Cetraria islandica (L) Ach. Journal of Ethnopharmacology, 79, 325-329. https://doi.org/10.1016/s0378-8741(01)00396-8

Harborne, J. B. (1973). Phytochemical methods. London: Chapman and Hall, Ltd. pp. 49-188. https://doi.org/10.4236/jmp.2010.130236,245

Huang, D., Ou, B., \& Prior, R. L. (2005). The Chemistry behind Antioxidant Capacity Assays. Journal of Agricultural and Food Chemistry, 53, 1841-1856. https://doi.org/10.1021/jf030723c

Ibrahim, H. O., Osilesi, O., Adebawo, O. O., Onajobi, F. D., Muhammad, L. B., \& Karigidi, K. O. (2019). In vitro Assessment of the Potential Antioxidant and Antidiabetic Properties of Edible Parts of Chrysophyllum albidum Fruit Extracts. Journal of Food and Nutrition Research, 7(2), 105-113. https://doi.org/10.12691/jfnr-7-2-2.

Ilavarasan, R., Malika, M., \& Venkataraman, S. (2006). anti-inflammatory and antioxidant activities of cassia fistula linn bark extracts. African Journal of Traditional, Complementary and Alternative Medicines, 2(1), 70-85. https://doi.org/10.4314/ajtcam.v2i1.31105

Kannan, R. R., Arumugam, R., Thangaradjou., T., \& Anantharaman, P. (2013). Phytochemical constituents, antioxidant properties and p-coumaric acid analysis in some seagrasses. Food Research International, 54(1), 1229-1236. https://doi.org/10.1007/s10661-013-3183-6

Kebieche, M. (2009). Antihyperglycemic, anti-diabetic and antioxidant effects of the n-Butanol extract (BE) obtained from air part of Ranunculus repens $L$ plant and quercetin were investigated in normal glucose-fed hyperglycemia, in alloxan induced diabetes and in epirubicin (EPI) toxicity of the rats. Doctor PhD Thesis. University Mentouri Constantine. pp. 1-143. Retrieved from http://hdl.handle.net/2268/75967

Kessler, M., Ubeaud, G., \& Jung, L. (2003). Anti- and pro-oxidant activity of rutin and quercetin derivatives. Journal of Pharmacy and Pharmacology, 55(1), 131-142. https://doi.org/10.1211/002235702559

Khan, R. A., Khan, M. R., Sahreen, S., \& Ahmed, M. (2012). Assessment of flavonoids contents and in vitro antioxidant activity of Launaea procumbens. Chemistry Central Journal, 6(1), 43. https://doi.org/10.1186/1752-153X-6-43

Khettaf, A., Belloula, N., \& Dridi, S. (2016). Antioxidant activity, phenolic and flavonoid contents of some wild medicinal plants in southeastern Algeria. African Journal of Biotechnology, 13, 524-530. https://doi.org/10.5897/AJB2015.14459

Kim, Y. S., Hwang, J. W., Sung, S. H., Jeon, Y. J., Jeong, J. H., \& Jeon, B. T. (2015). Antioxidant activity and protective effect of extract of Celosia cristata L. flower on tertbutyl hydroperoxide-induced oxidative hepatotoxicity. Food Chemistry, 168, 572-579. https://doi.org/10.1016/j.foodchem.2014.07.106

Kwon, Y. I., Apostolidis, E., \& Kim, Y. C. (2007). Shetty K. Health benefits of traditional corn, beans, and pumpkin: in vitro studies for hyperglycemia and hypertension management. Journal of Medicina Food, 10(2), 266-275. https://doi.org/10.1089/jmf.2006.234

Matsinkou, R. S., Ngondi, J. L., Kuate, D., Mbofung, C., \& Oben, J. E. (2012). Antioxidant and anti-hyperglycemic potential of pulp extracts of Irvingia wombolu fruits. Biology and Medicine, 4(1), 10-19. https://doi.org/10.5281/zenodo.997625

Mavi, A., Terzi, Z., Ozgen, U., Yildirim, A., \& Coskun, M. (2004). Antioxidant Properties of Some Medicinal Plants: Prangos ferulacea (Apiaceae), Sedum sempervivoides (Crassulaceae), Malva neglecta (Malvaceae), Cruciata taurica (Rubiaceae), Rosa pimpinellifolia (Rosaceae), Galium verum subsp. verum (Rubiaceae), Urtica dioica (Urticaceae). Biological \& Pharmaceutical Bulletin, 27, 702. https://doi.org/10.1248/bpb.27.702

Melius, P. (1971). Isolation of yeast invertase by sephadex gel chromatography. A biochemistry laboratory experiment. Journal of Chemical Education, 48(11), 765-766. https://doi.org/10.1021/ed048p765

Mensor, L. L., Menezes, F. S., Leitao, G. G., Reis, A. S., dos Santos, T. C., \& Coube, C. S. (2001). Screening of Brazilian plant extracts for antioxidant activity by the use of DPPH free radical method. Phototherapy 
Research, 15, 127-130. https://doi.org/10.1002/ptr.687

Miliauskas, G., Venskutonis, P. R., \& Van-Beek, T. A. (2004). Screening of radical scavenging activity of some medicinal and aromatic plant extract. Food Chemistry, 85(2), 231-237. https://doi.org/10.1016/j.foodchem.2003.05.007

Moukette, M. B., Pieme, C. A., Biapa, P. C. N., Moor, V. J. A., Berinyuy, E., \& Ngogang, Y. J. (2015). Afrostyrax lepidophyllus extracts exhibit in vitro free radical scavenging, antioxidant potential and protective properties against liver enzymes ion mediated oxidative damage. JE BMC Research Notes, 8(344), 1304-1308. https://doi.org/10.1186/s13104-015-1304-8

Moupela, C., Vermeulen, C., Daïnou, K., \& Doucet, J. K. (2011). Le noisetier d'Afrique (Coula edulis Baill.). Un produit forestier non ligneux méconnu. Biotechnology, Agronomy and Society and Environment, 15(3), 485-495.

Nickavar, B., \& Yousefian, N. (2009). Inhibitory effects of six Allium species on $\alpha$-amylase enzyme activity. Iran J Pharm Res, 8(1), 53-57. https://dx.doi.org/10.22037/ijpr.2010.788

Nunes, P. X., Silva, S. F., Guedes, R. J., \& Almeida, S. (2012). Biological oxidations and antioxidant activity of natural products. Phytochemicals as nutraceuticals -Global Approaches to Their Role in Nutrition and Health. pp. 1-20.

Oboh, G., Akinyemi, A. J., \& Ademiluyi, A. O. (2012). Inhibition of -amylase and -glucosidase activities by ethanolic extract of Telfairia occidentalis (fluted pumpkin) leaf. Asian Pacific Journal of Tropical Biomedicine, 2(9), 733-738. https://doi.org/10.1016/S2221-1691(12)60219-6

Oluyemi, K. A., Okwuonu, U. C., Baxter, D. G., \& Oyesola, T. O. (2007). Toxic effects of methanolic exract of Aspilia africana leaf on the estrous cycle and uterine tissues of Wistar rats. International Journal of Morphology, 25, 609-614. https://doi.org/10.4067/S0717-95022007000300023

Omoregie, E., \& Osagie, A. (2012). Antioxidant properties of methanolic extracts of some Nigerian Plants on nutritionally-stressed rats. Nigerian Journal of Basic and Applied Sciences, 20(1), 7-20. Retrieved from http://www.ajol.info/index.php/njbas/index

Pandey, K. B., \& Rizvi, S. I. (2009). Plant polyphenols as dietary antioxidants in human health and disease. Oxidative medicine and cellular longevity, 2(5), 270-278. https://doi.org/10.4161/oxim.2.5.9498

Prieto, P., Pineda, M., \& Aguilar, M. (1999). Spectrophotometric quantitation of antioxidant capacity through the formation of a phosphomolybdenum complex: specific application to the determination of vitamin $\mathrm{E}$. Analytical Biochemistry, 269(2), 337-341. https://doi.org/10.1006/abio.1999.4019

Proestos, C., Lytoudi, K., Mavromelanidou, O. K. Zoumpoulakis, P., \& Sinanoglou, V. J. (2013). Antioxidant Capacity of Selected Plant Extracts and Their Essential Oils. Antioxidants (Basel), 2(1), 11-22. https://doi.org/10.3390/antiox2010011

Raghuveer, C., \& Tandon, R. V. (2009). Consumption of functional food and our health concerns. Pakistan Journal of Physiology, 5, 76-83. Retrieved from http://www.pjp.pps.org.pk/index.php/PJP/article/view/713

Razali, N., Mat-Junit, S., Abdul-Muthalib, A. F., Subramaniam, S., \& Abdul-Aziz, A. (2012). Effects of various solvents on the extraction of antioxidant phenolics from the leaves, seeds, veins and skins of Tamarindus indica L. Food Chemistry, 131, 441-448. https://doi.org/10.1016/j.foodchem.2011.09.001

Re, R., Pellegrini, N., Preoteggente, A., Pannala, A., Yang, M., \& Rice-Evans, C. (1999). Antioxidant activity applying an improved ABTS radical cation decolorization assay. Free Radical Biology Medicine, 23(9-10), 121-137. https://doi.org/10.1016/S0891-5849(98)00315-3

Saeed, N., Khan, M. R., \& Shabbir, M. (2012). Antioxidant activity, total phenolic and total flavonoid contents of whole plant extracts Torilis leptophylla L. BMC Complementary and Alternative Medicine, 221, 1-12. https://doi.org/10.1186/1472-6882-12-221

Sahreen, S., Khan, M. R., \& Khan, R. A. (2011). Phenolic compounds and antioxidant activities of Rumex hastatus D. Don. Leaves. Journal of Medicinal Plants Research, 5, 2755-2765. http://www.academicjournals.org/JMPR

Sharififar, F., Dehghn-Nudeh, G., \& Mirtajaldini, M. (2009). Major flavonoids with antioxidant activity from Teucrium polium. L. Food Chemistry, 112, 885-888. https://doi.org/10.1016/j.foodchem.2008.06.064

Singh, D. K., Srivastava, B., \& Sahu, A. (2004). Spectrophotometric determination of Rauwolfia alkaloids: 
estimation of reserpine in pharmaceuticals., Analytical Science, 20(3), 571-573.

https://doi.org/10.2116/analsci.20.571

Sofowara, A. E. (1993). Medicinal plants and traditional medicine in Africa (2nd ed.). Ibadan, Nigeria: Spectrum books Ltd. https://doi.org/10.4314/ajtcam.v10i5.2

Squadrito, G. L., \& Pryor, W. A. (2002). Mapping the reaction of peroxynitrite with $\mathrm{CO}_{2}$ : energetics, reactive species, and biological implications. Chemical Research in Toxicology, 15, 885-895. https://doi.org/10.1021/tx020004c

Srinivasan, K. (2005). Role of species beyond food flavouring: Nutraceuticals with multiple health effects. Food Review International, 21, 167-188. https://doi.org/10.1081/FRI-200051872

Tamuly, C., Hazarika, M., Bora, J., \& Gajurel, P. R. (2014). Antioxidant Activities and Phenolic Content of Piper wallichii (Miq.) Hand.-Mazz. International Journal of Food Properties, 17(2), 309-320. https://doi.org/10.1080/10942912.2011.631250

Trease, G. E., \& Evans, W. C. (1989). Pharmacognsy. 11th edition. London: Brailliar Tiridel Can Macmillian Publishers, 60-75. https://doi.org/10.1002/jps.2600690550

Tylor, B. S., Kion, Y. M., Wang, Q. I., Sharpio, R. A., Billiar, T. R., \& Geller, D. A. (1997). Nitric oxide down regulates hepatocyte-inducible nitric oxide synthase gene expression. Archives of surgery, 132, 1177-1183. https://doi.org/10.1001/archsurg.1997.01430350027005

Umamaheswari, M., \& Chatterjee, T. K. (2007). In vitro antioxidant activities of the fractions of Coccinia grandis L. leaf extract. African Journal of Traditional, Complementary, and Alternative Medicines, 5(1), 61-73. https://doi.org/10.4314/ajtcam.v5i1.31258

Valko, M., Leibfritz, D., Moncol, J., Cronin, M. T. D., Mazur, M., \& Telser, J. (2006). International Journal of Biochemistry and Cell Biology, 7, 45. https://doi.org/10.1016/j.biocel.2006.07.001

Xiao, J., Ni, X., Kai, G., \& Chen, X. (2013). A review on structure-activity relationship of dietary polyphenols inhibiting $\alpha$-amylase. Critical Review in Food Sciences and Nutrition, 53(5), 497-506. https://doi.org/10.1080/10408398.2010.548108

Yazdanparast, R., \& Ardestani, A. (2007). In vitro antioxidant and free radical scavenging activity of Cyperus rotundus. Journal of Medicinal Food, 10, 667-674. https://doi.org/10.1089/jmf.2006.090

Yeh, J. Y., Hsieh, L. H., Wu, K. T., \& Tsai, C. F. (2011). Antioxidant Properties and Antioxidant Compounds of Various Extracts from the Edible Basidiomycete Grifola Frondosa (Maitake). Molecules, 16, 3197-3211. https://doi.org/10.3390/molecules16043197

Zhang, Y. J., Gan, R. Y., Li, S., Zhou, Y., Li, A. N., Xu, D. P., \& Li, H. B. (2015). Antioxidant Phytochemicals for the Prevention and Treatment of Chronic Diseases. Molecules, 20, 21138-21156.

https://doi.org/10.3390/molecules201219753

Zima, T., Fialora, L., Mestek, O., Janebora, M., Crkovska, J., \& Malbohan, I. (2001). Oxidative stress, metabolism of ethanol and alcohol-related diseases. Journal of Biomedical Sciences, 8, 59-70. https://doi.org/10.1007/BF02255972

Zofou, D., Tene, M., Ngemenya, M. N., Tane, P., \& Titanji, V. P. (2011). In vitro antiplasmodial activity and cytotoxicity of extracts of selected medicinal plants used by traditional healers of Western Cameroon. Malaria research and treatment, 42, 1-6. https://doi.org/10.4061/2011/561342

\section{Copyrights}

Copyright for this article is retained by the author(s), with first publication rights granted to the journal.

This is an open-access article distributed under the terms and conditions of the Creative Commons Attribution license (http://creativecommons.org/licenses/by/4.0/). 